\title{
Health Implication on Residents Close to Petrol Station in Ife Central, Nigeria
}

\author{
Oladele Eunice Abiola, Michael Ajide Oyinloye* \\ Department of Urban and Regional Planning, Federal University of Technology, Akure, Nigeria \\ Email address: \\ euniceoladele15@gmail.com (O. E. Abiola), maoyinloye@futa.edu.ng (M. A. Oyinloye), micnicjide@yahoo.com (M. A. Oyinloye) \\ ${ }^{*}$ Corresponding author
}

\section{To cite this article:}

Oladele Eunice Abiola, Michael Ajide Oyinloye. Health Implication on Residents Close to Petrol Station in Ife Central, Nigeria. Urban and Regional Planning. Vol. 6, No. 2, 2021, pp. 79-86. doi: 10.11648/j.urp.20210602.13

Received: March 27, 2021; Accepted: April 16, 2021; Published: April 26, 2021

\begin{abstract}
The emergence and indiscriminate siting of fuel petrol stations all across the country call for urgent investigation of the impact of their siting at close proximity to residential areas and absurd places at Ife Central, Nigeria. This project was conducted to analyse the health implication of residents close to the petrol stations in Ife Central, Nigeria. The spatial locational pattern of fuel stations was analysed and its resultant impact on Ife Central, Nigeria to determine the degree of compliance of the PFS with planning standards and regulations; proximity to health care centres, physical, the social and economic relationship between the PFS and residential land uses in the study area. Fifty-two (52) were sampled for data collection. A two-phase mixedmethod approach was adopted, using qualitative interviews to validate identified factors. Upon the validation of the location factors through an inductive approach, a quantitative questionnaire was formulated. Using a quantitative survey, data were collected from 340 respondents. The data were then analysed using factor analysis and structural equation modelling to determine the factors and their relationship with factors of location. The analysis reveals cumulative non-compliance to principles and standards by all the PFS. The PFS distribution was cluster distribution pattern of the fuel stations, portraying an unorganised distribution. This cluster distribution pattern impacts negatively on the residents' wellbeing, environment and socio-economic life. The study also identified owner preferential choice and planning standards; storage material and factor of location; environmental impact assessment; type of license; and distance between the tanks and site management and administration as the five factors that directly influenced the choice of location of the Petrol Filling Stations (PFS).
\end{abstract}

Keywords: Petrol Station, Health, Residential, Planning Standards

\section{Introduction}

Fuels are primarily hydrocarbons containing volatile organic compounds such as benzene, some of which are injurious and harmful if in contact with skin and as well posit low dosage upon exposure to it [1]. The safety of lives and properties and protection of the environment are therefore of major concerns revolving round the petrol filling stations. At ambient temperature, petrol and other vehicle fuels are potentially hazardous. Petrol gives off vapour when mixed with air in appropriate proportions. It burns with explosive force if ignited. Moreover, all petroleum products are potential pollutants, which, if not properly handled or managed, can damage the environment - injurious to aquatic life, and harmful to human health if inappropriately handled [2] Sequel to this development, many marketers take advantage of this need and build service station haphazardly without considering the possible effect of the locations of the stations. Sustainable economic development and activities such as population growth, urbanization, increased groundwater withdrawal for agriculture, absence of pollution control regulation etc. have been recognised as a major contributing factor of environmental degradation [3]. An improved understanding of natural resource base and mostly environmental systems that support national economies is needed for sustainable development patterns to be determined and recommended to the government. In recent years some scholars have carried out preliminary attempts in this field. Voiland pointed out that gas flaring affects the well-being of local communities; it poisons the environment and illuminates the skies in the evening [4]. The results of gas flaring include particle decomposition, sulphur dioxides, 
nitrogen dioxide, and carcinogenic organic instability. In the case of other gaseous outbreaks in populations, hazardous mixes seriously affect their wellbeing in the forms of respiratory illness, hypertension, diabetes, difficult coughing and chronic bronchitis. The source of acid rain which pollutes rivers and lakes and destroys vegetation was also identified as Flared gas [5].

Alam et al. in their research study showed that there was a significant difference from the control (those not working at the stations) in the lung functionality test results of petrol pump staff, which pointed to the fact chronic exposure to fuel fumes, hampers the mechanical properties of their breathing [6]. Blamah et al. considered the high risk and dangers associated with petroleum product as a highly inflammable product, its exploration, transportation, offloading, storing and sale points and facilities should not be taken for granted like other products [7]. The (United Nations [8]; World Health Organisation [9] pointed out that the health of the people living close to these areas become endangered as a result of constant exposure to traffic and vapour emission. Fuels dispensed at PFS most especially petrol contain volatile organic compounds like benzene which are flammable and can give off vapour even at low temperatures. Sangotola et al., said that that there is always a risk of fire or explosion if ignited [10]. Also, they float in water and many travel long distances eventually causing danger away from the place where they have escaped. The inhalation of petrol fumes constitutes a high potential risk to the environment and the general population. According to World Health Organisation report, more than 2.3 million lives and properties worth more than 4.5 billion are lost to fire outbreaks associated to petroleum product mishandling [11]. Daily Mail Reporter, 01:38 BST suggested that the location of filling stations and petroleum products should maintain some distance from public places because of their vulnerability, bad odour and air pollution [12]. They concluded that a minimum distance of 50 meters should be maintained between petrol stations and housing, and 100 meters facilities such as hospitals, health centres, schools, and old people's homes.

\section{Study Area}

The city of Ile-Ife (Figure 1) is the headquarter of Ife Central Local Government Area of Osun State, Nigeria. It is located on latitudes $7^{\circ} 26^{\prime} \mathrm{N}$ and $7^{\circ} 32^{\prime} \mathrm{N}$ of the equator and longitude $4^{\circ} 29^{\prime} \mathrm{E}$ and $4^{\circ} 37^{\prime} \mathrm{E}$ of the Meridian. The population of the area is about 167,254 persons consisting of 88,403 males and 78,801 females based on the 2006 census result [13]. The vegetation in Ile-Ife is made of three canopy heights the tallest trees up to $25 \mathrm{~m}$ high with canopies far apart, the middle layer $10-15 \mathrm{~m}$ high with rather discontinues and irregular canopy and the third layer comprises of dense saplings and shrubs generally less than $5 \mathrm{~m}$ high. The vegetation in Ile-Ife is made of three canopy heights the tallest trees up to $25 \mathrm{~m}$ high with canopies far apart, the middle layer $10-15 \mathrm{~m}$ high with rather discontinues and irregular canopy and the third layer comprises of dense saplings and shrubs generally less than $5 \mathrm{~m}$ high. The floor is originally covered by a fairly thick layer of little of a forest.

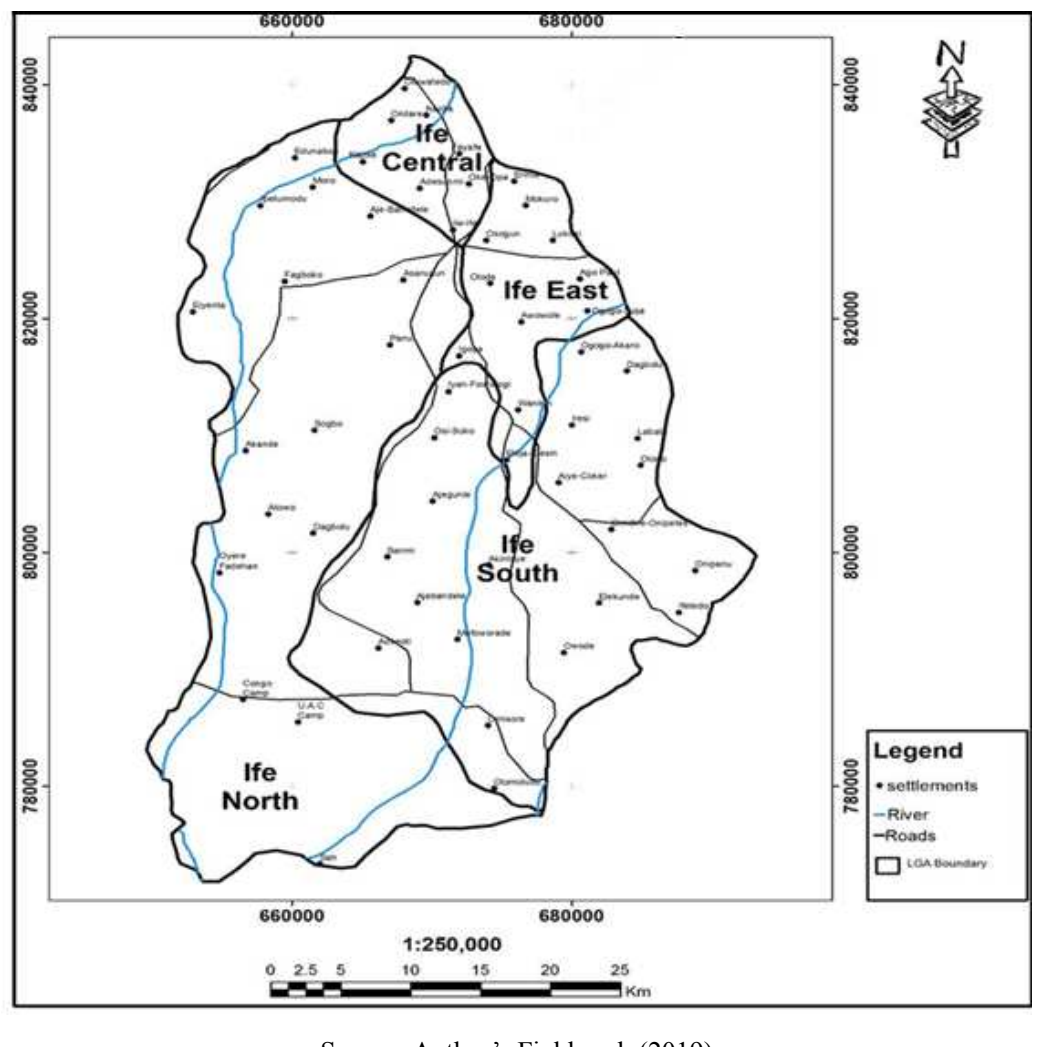

Source: Author's Fieldwork (2019)

Figure 1. Map of Ife showing Ife Central Local Government. 


\section{Materials and Methods}

The following data were used in carrying out this research work: The primary source included the administration of structured and unstructured questionnaires, oral interview, personal observation, topographical map of Ile-Ife of 1966 with the scale 1:50,000 produced by the survey department of the state, Geographic information system (GIS), Global Positioning System (GPS). Two different questionnaires were prepared; one for fuel station owners or managers and the other for residents in the study area. There were fifty-two fuel stations were covered or analysed in the study area and they were all enumerated to determine their level of compliance with the guidelines set by the Department of Petroleum Resources. The second questionnaire was used to conduct a survey of residents' opinion regarding the location of fuel stations and their implications around them. The entire filling stations located in the study area were altogether sampled. A purposive sampling method was adopted to administer questionnaires. This sampling technique represents a group of non-probability sampling techniques; and a judgmental or selective sampling of which the researcher relies on his whims and whims to select the respondent. A total of ten (10) respondents in close proximity to each petrol station were randomly sampled, forming the sample size for residents living around the filling station. A total of three hundred and forty (340) questionnaires were administered to get the necessary information for this research. The Global Positioning System (GPS) was used to pick the coordinates of the petrol stations in the study area, while the satellite imagery was used to randomly sample the number of buildings within 50 meters and 100 meters range to the petrol stations.

\section{Data Analysis and Presentation}

\subsection{Spatial Location of Petrol Stations and Their Coordinates}

The spatial distribution showing the locations of the PFS across the study area with the satellite imagery is presented in
Figure 2. From the figures, it is clear that the PFS is widely located across the study area, particularly along the major transportation routes of the town with concentration at the hub of the study area

Table 1. Socio-economic status of the respondents living in the neighbor.

\begin{tabular}{lll}
\hline Socio-economic & Frequency & Percent \\
\hline Gender of the respondents & & \\
Male & 181 & 53.2 \\
Female & 159 & 46.8 \\
Age distribution of the respondents & & \\
18-35 & 246 & 72.3 \\
36-60 & 89 & 26.2 \\
60 and above & 5 & 1.5 \\
Marital status of the respondents & & \\
Single & 157 & 46.2 \\
Married & 175 & 51.5 \\
Divorced & 8 & 2.4 \\
Educational qualification of the respondents & \\
Primary & 5 & 1.4 \\
Secondary & 137 & 40.3 \\
Tertiary & 171 & 50.3 \\
Technical & 27 & 8.0 \\
Occupation of the respondents & & \\
Farming & 4 & 1.2 \\
Trading & 180 & 52.9 \\
Civil servant & 43 & 12.6 \\
Others & 113 & 33.2 \\
Years & & \\
Less than 5 years & 53 & 15.6 \\
5-10 & 52 & 15.3 \\
10-20 & 71 & 20.9 \\
Above 20 & 164 & 48.2 \\
Total & 340 & 100 \\
Nativity of the Respondents & & \\
Native & 165 & \\
Non-Native & & \\
Total & & \\
\hline & & \\
Sila & & \\
\hline
\end{tabular}

Source: Author's Fieldwork (2018)

The geographic coordinates of all the petrol filling stations in the study area are presented in Table 2.

Table 2. Names and coordinates of petrol stations.

\begin{tabular}{lllll}
\hline SN & Longitude & Latitude & Petrol Stations & Streets Name \\
\hline 1 & 671883.00 & 826751.00 & Dee Miskaf Energy Resource & Aderemi Road \\
2 & 671924.00 & 826707.00 & Total Arubidi & Aderemi Road \\
3 & 673270.11 & 829167.54 & Emerald Light & Aladanla \\
4 & 673287.11 & 829267.54 & Total & Aladanla \\
5 & 673770.11 & 833884.54 & SDG Mult Ilink Venture & Edakowe \\
6 & 668305.11 & 828872.54 & Poplat Service Station & Fajuyi \\
7 & 672065.11 & 828793.54 & Amazing Investment & Fajuyi \\
8 & 672291.11 & 828793.54 & Forte Oil & Fajuyi \\
9 & 672380.11 & 828878.54 & Raynud & Hezekiah Oluwasanmi Road \\
10 & 670811.00 & 829679.00 & Ayofat Global Services Ltd & Hezekiah Oluwasanmi Road \\
11 & 670871.00 & 829607.00 & Fotab & Hezekiah Oluwasanmi Road \\
12 & 671298.00 & 829039.00 & Olafat Unique Concept Ltd & Ibadan Road \\
13 & 666621.11 & 828905.54 & Basic Connextion & Ibadan Road \\
14 & 666765.11 & 828928.54 & Eko Oil \& Gas & Ibadan Road \\
15 & 666357.11 & 828911.54 & Folab & Ibadan Road \\
16 & 666707.11 & 828899.54 & & \\
\hline
\end{tabular}




\begin{tabular}{|c|c|c|c|c|}
\hline SN & Longitude & Latitude & Petrol Stations & Streets Name \\
\hline 17 & 668356.00 & 828505.00 & Energy Oil and Gas & Ife-Ibadan Express Road \\
\hline 18 & 668898.00 & 828226.00 & Poplat & Ife-Ibadan Express Road \\
\hline 19 & 672510.00 & 827517.00 & Sam'd Oil & Ifewara Road \\
\hline 20 & 674082.11 & 830514.54 & Gboye Investment & Ikoyi \\
\hline 21 & 672934.11 & 828946.54 & Hammedal & Ilesha Garage \\
\hline 22 & 671508.00 & 827628.00 & Total & Iremo Road \\
\hline 23 & 664499.11 & 830626.54 & Friend Top & Kajola Akile Alewe Eran \\
\hline 24 & 674085.11 & 830699.54 & Adunfak Investment & Kojumole \\
\hline 25 & 670701.11 & 827859.54 & Conoil Burnt & Lagere \\
\hline 26 & 670315.11 & 827982.54 & MRS Petrol Station & Lagere \\
\hline 27 & 670498.11 & 827924.54 & Poplat & Lagere \\
\hline 28 & 670172.11 & 828051.54 & Total & Lagere Ife-Ile \\
\hline 29 & 670304.11 & 827987.54 & Tentacle Investment & Lagere Ife-Ile \\
\hline 30 & 669562.11 & 828057.54 & Access Inter-Biz & Mayfair Road \\
\hline 31 & 669169.11 & 828121.54 & Bofat Petrol & Mayfair Road \\
\hline 32 & 669363.11 & 828069.54 & Exodus Petrol Station & Mayfair Road \\
\hline 33 & 669027.11 & 828271.54 & Metrol Petrol Station & Mayfair Road \\
\hline 34 & 672889.00 & 828388.00 & Bovas & More Road \\
\hline 35 & 672780.00 & 828069.00 & Olafat Unique Concept Ltd & More Road \\
\hline 36 & 673067.00 & 828834.00 & Simeon's Oil Nigeria Ltd & More Road \\
\hline 37 & 670830.00 & 827812.00 & Oando & No 1 Aderemi Road \\
\hline 38 & 670996.00 & 827620.00 & Dollars Oil Petroleum & No 28 Aderemi Road \\
\hline 39 & 673580.11 & 829870.54 & Adegboye General Enterprise & OAU Phase 2 \\
\hline 40 & 673606.11 & 829921.54 & Total & OAU Phase 2 \\
\hline 41 & 673880.11 & 830179.54 & Meritan Oil \& Chemical & OAU Phase 3 \\
\hline 42 & 673470.11 & 829698.54 & NIPCO & OAU Phase 1 \\
\hline 43 & 665201.11 & 828811.54 & Oando Petrol \& Gas & Ooni Layout Ibadan Road \\
\hline 44 & 673824.11 & 832286.54 & Latosen Petrol Investment & Opa \\
\hline 45 & 673707.11 & 831754.54 & Virgo Service & Opa \\
\hline 46 & 674381.00 & 828995.00 & Keto Oil & Reinhard Bonnke Road \\
\hline 47 & 668139.44 & 829131.83 & AP Oil & Road 1 OAU Campus \\
\hline 48 & 671784.11 & 828415.54 & BOVAS & Sabo Junction \\
\hline 49 & 671513.11 & 828251.54 & Forte Oil & Sabo Junction \\
\hline 50 & 665782.11 & 828964.54 & Adeyanju & Toll Gate \\
\hline 51 & 664652.11 & 828595.54 & Dollas & Toll Gate \\
\hline 52 & 664925.11 & 828692.54 & Segfar Petrol \&Gas & Toll Gate \\
\hline
\end{tabular}

Source: Author's Fieldwork (2018)

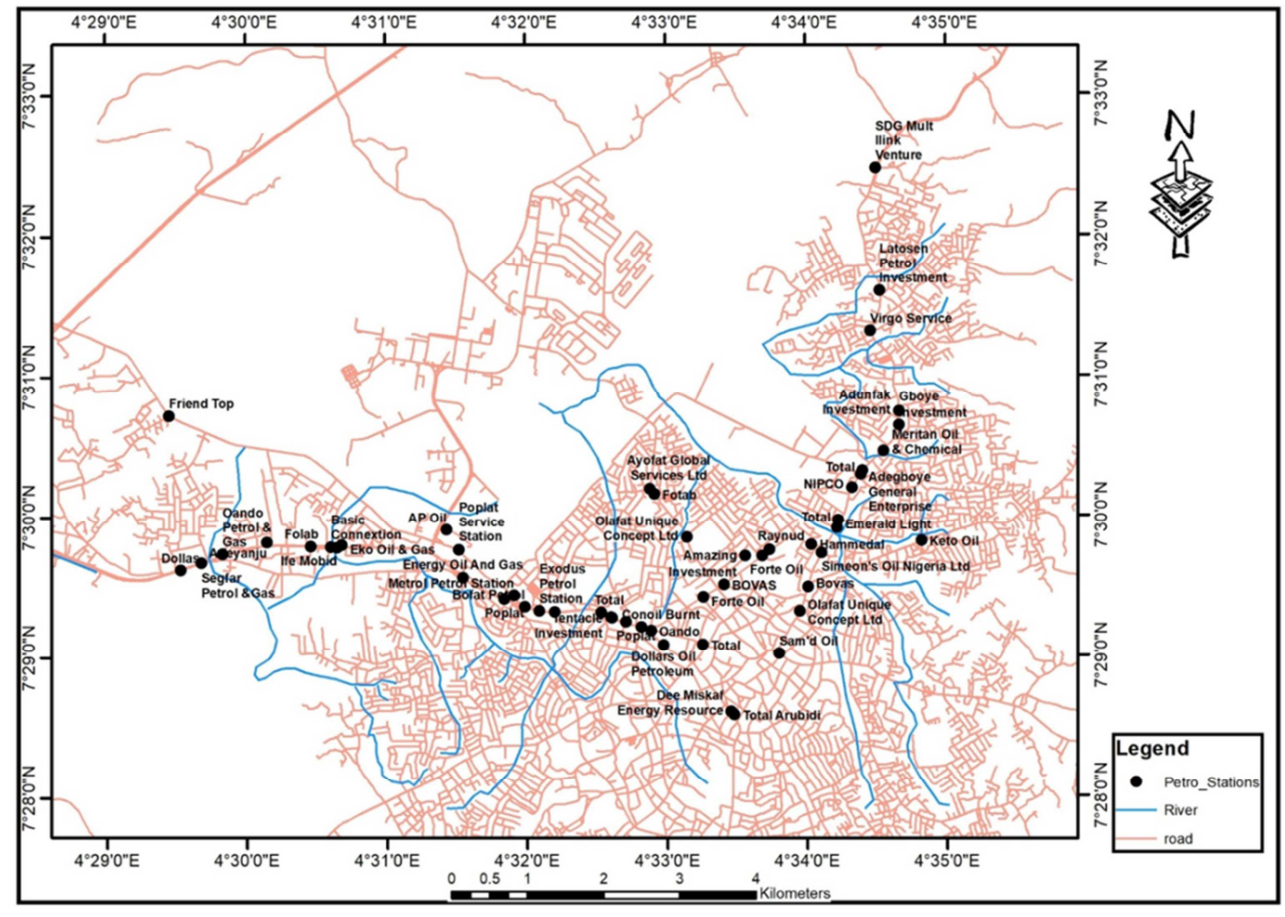

Source: Author's Fieldwork (2019)

Figure 2. Spatial distributions of petrol stations Ile-Ife Central. 


\subsection{Setback to the Health Care}

The setback of the petrol stations to health care is presented in Table 3. The result shows that $50 \mathrm{~m} \mathrm{36.5 \% ,} 100$ m $5.8 \%, 150 \mathrm{~m} 19.2 \%$ and $200 \mathrm{~m} 38.5 \%$. According to the criteria set by the DPR, filling stations are not allowed to operate adjacent to public institutions like hospitals. In case they are to operate, a minimum distance of 100 meters has to be maintained.
Table 3. Distance from health care.

\begin{tabular}{lll}
\hline Distance from Health care & Frequency & Per cent \\
\hline 50 & 19 & 36.5 \\
100 & 3 & 5.8 \\
150 & 10 & 19.2 \\
200 & 20 & 38.5 \\
Total & 52 & 100.0 \\
\hline
\end{tabular}

Source: Author's Fieldwork (2018)

Table 4. Factor loadings after Varimax rotation.

\begin{tabular}{llllll}
\hline & D1 & D2 & D3 & D4 & D5 \\
\hline Distance to built-up area & 0.8063 & 0.0666 & -0.0158 & 0.0537 & -0.2513 \\
Turning radius & 0.7794 & 0.0937 & -0.1777 & -0.2660 & 0.1908 \\
Setback to residential landuse & 0.7172 & 0.3910 & -0.2197 & 0.0944 & 0.1969 \\
Pump setback to pavement & 0.6862 & -0.2003 & 0.2795 & -0.0192 & 0.0723 \\
Reason for location & 0.6439 & -0.0598 & -0.0030 & 0.5778 & -0.2096 \\
Distance to the road & 0.5814 & 0.3740 & -0.0462 & -0.2134 & -0.3293 \\
Material for storage & 0.0573 & 0.8800 & -0.0652 & 0.0222 & 0.1291 \\
Factors influencing location & 0.2151 & 0.5933 & 0.3205 & -0.1197 & 0.3528 \\
Suitability before siting & -0.1245 & 0.1458 & 0.7647 & 0.0956 & 0.2499 \\
Assessment before siting & 0.0849 & -0.1609 & 0.7068 & -0.1342 & 0.0516 \\
Approved by govt & 0.0157 & -0.0423 & 0.6609 & 0.0103 & 0.2493 \\
Original land use & 0.0731 & -0.2701 & -0.5450 & 0.0529 & 0.2518 \\
Distance between the tanks & -0.1384 & -0.1248 & -0.1343 & 0.7133 & 0.2950 \\
Type of licence required & -0.0654 & 0.4826 & -0.0014 & 0.6286 & -0.3067 \\
Other services in the stations & -0.0997 & 0.0743 & 0.1361 & 0.2381 & 0.7583 \\
Size of the station & 0.2827 & 0.2667 & 0.1561 & 0.1195 & 0.5159 \\
Distance from healthcare & 0.1459 & -0.0728 & -0.0505 & 0.2607 & -0.7772 \\
Setback to infrastructure & 0.0544 & 0.2354 & -0.2738 & 0.1964 & 0.1317 \\
\hline
\end{tabular}

Extraction Method: Principal Component Analysis.

Rotation Method: Varimax with Kaiser Normalization

Source: Author's Fieldwork, (2018)

\subsection{Awareness of Residents and PFS Operators on the Locational Effect of PFS on Residential Land Use}

The study revealed that there is a high level of awareness among the residents on the impact of siting the PFS close to residential land use on the wellbeing (health) of residents and the environment. The result revealed that $56.2 \%$ were aware of the potential risks associated with the PFS both to the health of the residents and the environment, while $43.8 \%$ tend to not attach any risk with the PFS location and services (Table 5).

Table 5. Health risk of the respondents.

\begin{tabular}{lll}
\hline Health risk & Frequency & Per cent \\
\hline Yes & 191 & 56.2 \\
No & 149 & 43.8 \\
Total & 340 & 100 \\
\hline
\end{tabular}

Source: Author’s Fieldwork, (2018)

The awareness of health-related issues by the petrol stations operators in the study area is presented in Table 6 . The result shows that the operators of the PFS claimed ignorance of the impact of their business on the residents and the environment as $37.8 \%$ claimed to be aware of the effect, while $62.2 \%$ claimed ignorance of associated and impacted health problems.

The complaints of the residents around the petrol stations present a wide range of health challenges they encounter
(Table 7.) The results show that respiratory disease as the highest percentage of $73.1 \%$, nervous system breakdown and others returned $11.5 \%$ each and leukaemia $3.8 \%$. This wide range of these health threats was obtained based on the perception of the residents concerning the distance between the petrol stations and their residential houses. This is with the view to determine the variation in the risk variables.

The respondents also presented common ailments peculiar to them in Table 8. The results show that fever and cough each return $38.8 \%$, while cold and asthma $13.8 \%$ and $8.5 \%$ respectively as shown in Table 8 .

The study, therefore, reveals that residents in close proximity to these petrol stations suffer respiratory-related health problems. "This finding is consistent with the report of Mshelia which submitted that PFS or related activities releasing fuel gasses into the atmosphere produce environmental hazards that present health hazards when inhaled, swallowed or in contact with the skin or eye" [14].

Table 6. Awareness of health-related issue by the PFS Operators.

\begin{tabular}{lll}
\hline Awareness & Frequency & Per cent \\
\hline Yes & 14 & 37.8 \\
No & 23 & 62.2 \\
Total & 37 & 100 \\
\hline
\end{tabular}

Source: Author's Fieldwork, (2018) 
Table 7. Health complaint.

\begin{tabular}{lll}
\hline Health complaint & Frequency & Per cent \\
\hline Leukaemia & 2 & 3.8 \\
nervous system breakdown & 6 & 11.5 \\
respiratory diseases & 38 & 73.1 \\
Others & 6 & 11.5 \\
Total & 52 & 100.0 \\
\hline
\end{tabular}

Source: Author's Fieldwork, (2018)

Table 8. Common ailments of the respondents.

\begin{tabular}{lll}
\hline Common ailment & Frequency & Per cent \\
\hline Fever & 132 & 38.8 \\
Cough & 132 & 38.8 \\
Cold & 47 & 13.8 \\
Asthma & 29 & 8.5 \\
Total & 340 & 100 \\
\hline
\end{tabular}

Source: Author's Fieldwork, (2018)

\subsection{Hazard Occurrence(s) of PFS in the Study Area}

The occurrence of a fire outbreak in the petrol station is presented in Table 9. The study showed $82.7 \%$ of the PFS claimed that they had not experienced any case fire outbreak, while $17.3 \%$ claimed to have encountered such. This might be due to some cautions are taken in simple compliance with some rules such as no smoking, no use of phone, and others in the areas of dispense of fuel. This implies that fire extinguisher is very important in case of any fire outbreak in the petrol station to avoid casualties.

The study also showed the safety measures each station employs to combat the occurrence of the fire accidents. Over $98 \%$ of the PFS in the study area claimed to be equipped with a functional fire extinguisher in any case of fire occurrence, and about $2 \%$ claimed to be equipped with sand buckets for the same purpose (Table 10). This revealed that all the PFS knew potential hazards associated with their services and are at least equipped for the one they can handle.

Table 9. Fire outbreak in the petrol station.

\begin{tabular}{lll}
\hline Any fire outbreak & Frequency & Per cent \\
\hline Yes & 9 & 17.3 \\
No & 43 & 82.7 \\
Total & 52 & 100 \\
\hline
\end{tabular}

Source: Author's Fieldwork, (2018)

Table 10. Environmental safety measure.

\begin{tabular}{lll}
\hline Environmental safety measure & Frequency & Per cent \\
\hline Fire Extinguisher & 51 & 98.08 \\
Sand & 1 & 1.92 \\
Total & 52 & 100.00 \\
\hline
\end{tabular}

Source: Author's Fieldwork, (2018)

The residents have been feeling the impact of the PFS siting close to the residential areas, they presented the highest challenges they encounter is parking inconveniences which constitute about $50 \%$ of the complaints, traffic congestion was about $40 \%$ and pollution (water, soil and air) was about $5 \%$ (Table 11).
Table 11. Environmental complaint by the respondents.

\begin{tabular}{lll}
\hline Environmental complaints & Frequency & Per cent \\
\hline traffic congestion & 8 & 40 \\
pollution & 1 & 5 \\
parking inconveniences & 10 & 50 \\
others & 1 & 5 \\
Total & 20 & 100 \\
\hline
\end{tabular}

Source: Author's Fieldwork, (2018)

\subsection{Type of Pollution in the Environment Caused by Petrol Stations}

The impact of PFS on the surrounding has become noticeable to the residents, and Table 12. has a summary of their observation. The results show that the impact of the PFS activities and services on the air is conspicuous to the respondents and in fact constituted the highest percentage of air pollution $30.3 \%$, noise pollution and unnecessary traffic also bore great impact with $22.9 \%$ and $26.2 \%$ respectively; water being polluted is high with $17.9 \%$, and soil pollution with $2.6 \%$.

The result, therefore, indicates that air pollution has the highest per cent $(30 \%)$. This reveals that air pollution is the highest danger in relation to the distance between petrol stations and residential settlements. That is, the closer the houses are to the petrol stations, the more likely the residents will be exposed to air pollution as vehicles move in and out of petrol stations to take fuel and the use of generators to power-pumping machines. Soil pollution, water pollution, noise pollution and unnecessary traffic have $2.6 \%, 17.9 \%$, $22.9 \%$ and $26.2 \%$ respectively. This means the three variables are less severe compared to air pollution. However, the result equally shows that the nearer the petrol station to residential areas; the more likely the residents will be affected by traffic congestion, especially during fuel scarcity.

Table 12. Type of Pollution in the environment caused by petrol stations.

\begin{tabular}{lll}
\hline Type of pollutions & Frequency & Per cent \\
\hline Soil pollution & 9 & 2.6 \\
Air pollution & 103 & 30.3 \\
Water pollution & 61 & 17.9 \\
Noise pollution & 78 & 22.9 \\
Unnecessary traffic & 89 & 26.2 \\
Total & 340 & 100 \\
\hline
\end{tabular}

Source: Author's Fieldwork, (2018)

\subsection{Socio-economic Life}

The respondents in the study area presented their views despite the mixed impacts of the PFS on the socio-economic life of the area in Table 13. The results show that about $47 \%$ of the respondents opine the siting of the PFS close to the residential areas was good (very good $31.5 \%$ and good $15.9 \%$ ), while about $24.4 \%$, opined their siting was not good and $28.2 \%$ were indifferent

This opinion reveals perhaps the degree of the impact each respondent was exposed to. some were blinded perhaps with livelihood they make because of the siting of the PFS at the expense of their wellbeing. While those with outright displeasure were those who tasted the bitter pill of the 
negative impact of the PFS directly or indirectly.

The opinion of the respondents on their social-economic life in the study area is presented in Table 14. The result shows that $25.6 \%$ opined that the social-economic life in the area was excellent; $29.5 \%$ claimed it was very good $34.1 \%$ voted for average socio-economic life and $10.9 \%$ very bad.

The implication of the pattern observed in the study area is that a clustered pattern has a higher concentration of petrol service station which may cause problems like traffic congestion, pollution, fire and explosion and these numbers of petrol service stations competing with residential buildings. An urban planner faces challenges of the location of facilities and services which, as a result, exposes our urban populace to some dangers. Since road transport remains a common mode of transportation in the study number of vehicles increases on a daily basis, this translates to higher consumption of petrol. Hence, indiscriminate locations of a petrol service station.

Table 13. Opinion of petrol Stations by the respondents.

\begin{tabular}{lll}
\hline Opinions & Frequency & Per cent \\
\hline Very good & 107 & 31.5 \\
Good & 54 & 15.9 \\
Not good & 83 & 24.4 \\
Fair & 96 & 28.2 \\
Total & 340 & 100 \\
\hline
\end{tabular}

Source: Author's Fieldwork, (2018)

Table 14. Social-economic life of the respondents.

\begin{tabular}{lll}
\hline Social-economic life & Frequency & Per cent \\
\hline Excellent & 87 & 25.6 \\
Very good & 100 & 29.4 \\
Average & 116 & 34.1 \\
Very bad & 37 & 10.9 \\
Total & 340 & 100 \\
\hline
\end{tabular}

Source: Author's Fieldwork, (2018)

Table 15. shows the correlation which exists between various response variables of the respondents. Health risks presented by siting the PFS close to residential areas is statistically significant to the opinion on gas stations, common ailments and socio-economic life of the respondents.

The type of pollution experienced by the respondents is statistically significant to water pollution, common ailments and opinions of respondents on gas stations. Likewise, proximity to the gas stations of the respondents is significant to the common ailments experienced by the respondents. The opinions of respondents on gas stations are also statistically significant to the socio-economic life of the respondents.

Table 15. Correlation of respondents' responses p-values (Pearson).

\begin{tabular}{|c|c|c|c|c|c|c|c|}
\hline Variables & Health risk & $\begin{array}{l}\text { Type of } \\
\text { pollution }\end{array}$ & $\begin{array}{l}\text { Water } \\
\text { pollution }\end{array}$ & $\begin{array}{l}\text { Proximity to } \\
\text { gas stations }\end{array}$ & $\begin{array}{l}\text { Opinion on } \\
\text { gas station }\end{array}$ & $\begin{array}{l}\text { Socio- } \\
\text { economic life }\end{array}$ & $\begin{array}{l}\text { Common } \\
\text { ailments }\end{array}$ \\
\hline Health risk & 0 & & & & & & \\
\hline Type of pollution & 0.130 & 0 & & & & & \\
\hline Water pollution & 0.174 & $<0.0001$ & 0 & & & & \\
\hline Proximity to gas station & 0.530 & 0.684 & 0.132 & 0 & & & \\
\hline Opinion on gas station & $<0.0001$ & 0.022 & 0.046 & 0.403 & 0 & & \\
\hline Social economic life & 0.0002 & 0.052 & 0.310 & 0.129 & $<0.0001$ & 0 & \\
\hline
\end{tabular}

Values in bold are different from 0 with a significance level alpha $=0.05$

Table 15. above shows the correlation which exists between various response variables of the respondents. Health risks presented by siting the PFS close to residential areas is statistically significant to the opinion on gas stations, common ailments and socio-economic life of the respondents.

The type of pollution experienced by the respondents is statistically significant to water pollution, common ailments and opinions of respondents on gas stations. Likewise, proximity to the gas stations of the respondents is significant to the common ailments experienced by the respondents. The opinions of respondents on gas stations are also statistically significant to the socio-economic life of the respondents.

\section{Conclusions}

Based on the analysis done and the result obtained or presented, it can be concluded that:

1. The spatial distribution pattern of PFS at Ife Central, Nigeria is clustered using ArcGIS tool.

2. There was partial compliance with the principles, standards from concerned regulatory, monitoring planning bodies from the side sides of the PFS. No single PFS met the cumulative standards.

3. Using factor analysis and structural equation modelling, five factors were identified to have influenced the choice factors of locating the PFS, they are owner preferential choice and planning standards, storage material and factor of location, environmental impact assessment, type of license and distance between the tanks and site management and administration.

4. The clustered distribution pattern of the PFS impacted both on the wellbeing of the residents and the environment. Traffic congestion, parking inconveniences, noise pollution characterised the environmental discomfort created. Also, air pollution, noise pollution and water were strongly identified as the resultant effect of the services and operations of the PFS. Soil pollution was also identified.

5. The services of the PFS had negative impacts on the wellbeing of the residents, as respiratory diseases top the list, leukaemia and nervous breakdown was also reported. This confirmed the literature, thus 
categorising them as long-term non-carcinogenic health problems. Short-term health issues were also reported for being exposed to the vapours of gasoline dispensed by the PFS, they include fever, diarrhoea, cough, and cold.

6. The study revealed that there was a high level of awareness among the residents on the health and environmental effect of the PFS in the area. While there was low awareness among the PFS operators on the impact of their activities.

7. Non-synergetic principles and standards had been observed between the regulatory bodies and the local authorities

\section{References}

[1] Linet, M. S., Yin, S.-N., Travis, L. B., Li, C.-Y., Zhang, Z.-N., Li, D.-G. Group, T. B. S. (1996). Clinical features of hematopoietic malignancies and related disorders among benzene-exposed workers in China. Environmental Health Perspectives, 104, 1353-1364. https://doi.org/10.2307/3433190

[2] Health and Safety Executive. (2018). Storing petrol safely. http://www.hse.gov.uk/fireandexplosion/petroleum.hm

[3] Bowonder, B., \& Ramana, K. V. (1987). Environmental degradation and economic development: A case study of a marginally productive area. Applied Geography, 7 (4), 301315. https://doi.org/10.1016/0143-6228(87)90022-1

[4] Voiland, A. (2016, March 8). Methane Matter: Scientists work to quantify the effects of a potent greenhouse gas. Retrieved from

https://earthobservatory.nasa.gov/features/MethaneMatters

[5] Nduka, J. K., Okafor, V. N., \& Odiba, I. O. (2016). Impact of Oil and Gas Activities on Acidity of Rain and Surface Water of Niger Delta, Nigeria: An Environmental and Public Health Review. Journal of Environmental Protection, 07 (04), 566581. https://doi.org/10.4236/jep.2016.74051
[6] Alam, R., Zafar, A., Ghafoor, A., Naseem, A., Ali, Q., \& Imtiaz, F. (2014). Lung function abnormalities among fuel filling workers in Karachi, Pakistan. Pinnacle Environmental \& Earth Sciences, 1 (1), 183-187.

[7] Blamah, N. V., Vivan, E. L., Tagwi, M. U., \& Ezemokwe, I. U. (2012). Locational impact assessment of petrol service stations along Abuja-Keffi road and environs in Karu, Abuja, Nigeria. Journal of Environmental Management and Safety, 3 (5), 106-123. www.cepajournal.com

[8] United Nations (2014). World's Population increasingly urban with more than half living in the urban areas Retrieved from (Web).

[9] World Health Organization (2010). World health Day 2010: Why urban health matters Geneva, Switzerland. Retrieved from http://.who.int/features/2010/urban_health/en/

[10] Sangotola, T. M., Fasanmade, P. A., Ayanrinde, W. A., Olatinwo, I. O., \& Olaniran, H. F. (2015). On the effects of petrol stations in Nigeria. International Journal of Science, Engineering and Technology Research (IJSETR), 4 (4), 947954.

[11] World Health Organization (2014). Safe Piped Water: Managing Microbial Water Quality in Piped Distribution Systems by Richard Ainsworth

[12] Daily Mail Reporter (01:38 BST, 2011, February 8). Living near a petrol station is 'bad for your health' as fuel pollutants found to travel 100m: Mail Online. Department of Petroleum Resources. In the beginning. Retrieved from https://www.dpr.gov.ng/history-of-dpr/

[13] Nigeria Population Commission. (2007). Official Gazette on the National and State Provisional Totals: 2006 Census (No. 24). Federal Government Printer, 94.

[14] Mshelia, A. M., John, A., \& Emmanuel, D. D. (2015). Environmental effects of petrol stations at close proximities to residential buildings in Maiduguri and Jere, Borno State, Nigeria. IOSR Journal of Humanities and Social Science, 20 (4), 1-8. 